Sains Malaysiana 50(9)(2021): 2687-2700

http://doi.org/10.17576/jsm-2021-5009-16

\title{
Cardiac Depressant and Vasodialatory Effect of Flaxseed - Basis for the Medicinal Use in Hypertension
}

(Tekanan Jantung dan Kesan Kevasokembangan Biji Rami - Asas untuk Penggunaan Ubatan dalam Tekanan

Darah Tinggi)

\author{
Amber Hanif Palla, Najeeb Ur Rehman*, Hasan Salman Siddigi, Anwar-Ul-Hassan Gilani, Bina \\ SHAHEEN SidDiqui, MAIMOONA ILYAS \& SOBIYA PERWAIZ
}

\begin{abstract}
Linum usitatissimum (Flaxseed) is known to be traditionally used for managing hypertension. In this study, we aim to provide a mechanistic basis for the medicinal use of Flaxseed in hypertension. The high-performance liquid chromatography (HPLC) analysis that we carried out during our study showed the presence of polar compounds (quercetin, nicotinic acid, and nicotinamide) in Flaxseed's crude extract (Fs.Cr; aqueous methanolic). In anesthetized rats, Fs. Cr reduced arterial blood pressure (BP) dose-dependently (10-100 $\mathrm{mg} / \mathrm{kg})$. When tested for its mechanism of action ex vivo, Fs.Cr inhibited both the force and rate of spontaneous contractions in the dose range of 1-10 $\mathrm{mg} /$ $m L$ in isolated guinea-pig atria, similar to how verapamil, a standard $\mathrm{Ca}^{+2}$ channel blocker does it. Further, Fs. Cr showed vasodilator effect against the contractions induced by phenylephrine $(P E, 1 \mu \mathrm{M})$ in rat aortic ring preparations (concentration range: $1-10 \mathrm{mg} / \mathrm{mL}$ ), whereas no effect was observed against the contractions induced by low $K^{+}$ $(25 \mathrm{mM})$ as well as high $\mathrm{K}^{+}(80 \mathrm{mM})$. This selective inhibitory effect of Fs. Cr against PE was tested for endotheliumdependent nitric oxide (NO) and/or cholinergic component involvement. The vasodilator effect of Fs.Cr against PE was retested in the absence and presence of atropine in endothelium (E)-intact and E-denuded aorta, but no significant shift was observed in the inhibitory effect of Fs.Cr. Further, Fs.Cr shifted the PE-induced concentration-response curves (CRCs) to the right in a dose-dependent manner (1 and $3 \mathrm{mg} / \mathrm{mL}$ ). This effect was similar to that of prazosin. All these findings indicate that Flaxseed may mediate its antihypertensive activity by the alpha-1 receptor antagonist and $\mathrm{Ca}^{+2}$ channel blocking-like activity, which may account for its efficacy in hypertension.
\end{abstract}

Keywords: Alpha-1 Receptor antagonist; aorta; atria; Flaxseed; hypertension; vasodilator

ABSTRAK

Linum usitatissimum (Biji rami) diketahui secara tradisi digunakan untuk mengawal tekanan darah tinggi. Tujuan kajian ini adalah untuk memberikan dasar mekanistik penggunaan Biji rami dalam tekanan darah tinggi. Analisis kromatografi cecair berprestasi tinggi (HPLC) yang kami jalankan menunjukkan adanya sebatian polar (quersetin, asid nikotinik dan nikotinamida) dalam ekstrak kasar Biji rami (Fs.Cr; metanolik berair). Pada tikus yang dibius, Fs. Cr mengurangkan tekanan darah arteri (BP) bergantung pada dos (10-100 mg/kg). Semasa diuji untuk mekanisme tindakannya ex vivo, Fs.Cr menghalang kekuatan dan kadar kontraksi spontan dalam julat dos 1-10 mg/mL di atria tikus belanda yang terpencil, serupa dengan bagaimana verapamil, $\mathrm{Ca}^{+2}$ standard penyekat saluran melakukannya. Selanjutnya, Fs.Cr menunjukkan kesan kevasokembangan terhadap kontraksi yang disebabkan oleh fenilefrina (PE, $1 \mu M)$ pada persiapan cincin aorta tikus (julat kepekatan: $1-10 \mathrm{mg} / \mathrm{mL}$ ), sedangkan tidak ada kesan yang diamati terhadap kontraksi yang disebabkan oleh $\mathrm{K}^{+}$rendah $(25 \mathrm{mM})$ serta tinggi $\mathrm{K}^{+}(80 \mathrm{mM})$. Kesan penghambatan selektif Fs. Cr terhadap PE diuji untuk penglibatan komponen nitrat oksida (NO) dan/atau kolinergik yang bergantung pada endotelium. Kesan kevasokembangan Fs.Cr terhadap PE diuji semula dengan ketiadaan dan kehadiran atropin dalam aorta endotelium (E)-intact dan E-denuded, tetapi tidak ada perubahan yang ketara dalam kesan penghambatan Fs.Cr. Selanjutnya, Fs.Cr mengalihkan lengkung tindak balas kepekatan yang disebabkan oleh PE (CRC) ke kanan 
dengan cara yang bergantung pada dos (1 dan $3 \mathrm{mg} / \mathrm{mL}$ ). Kesan ini serupa dengan prazosin. Semua penemuan ini menunjukkan bahawa Biji rami dapat memediasi aktiviti antihipertensi oleh antagonis reseptor alfa-1 dan aktiviti seperti penyekat saluran $\mathrm{Ca}^{+2}$, yang mungkin menyumbang kepada keberkesanannya dalam hipertensi.

Kata kunci: Antagonis reseptor alfa-1; aorta; atria; Biji rami; kevasokembangan; tekanan darah tinggi

\section{INTRODUCTION}

According to the World Health Organization (WHO 2014 ), $60 \%$ of all deaths in the world are from chronic diseases, and globally, one out of every three adults is a victim of high BP i.e. hypertension. Due to the widespread prevalence of this disease and its ability to damage vital organs, this disease poses a significant healthcare challenge (Cutler et al. 2008). The available treatment options require life-long use of multiple expensive drugs that are not only beyond the reach of the common people of this country but are also associated with multiple side-effects (Ghayur \& Janssen 2010). This leads to noncompliance issues which subsequently lead to a person being at high risk of experiencing cardiovascular events (Mazzaglia et al. 2009).

Natural products offer a solution to this problem as they can simultaneously cater to multiple triggers of a disease with a relatively better safety profile than pure chemicals do. The use of natural products is also in line with the recent recommendations in the hypertension management guidelines. These guidelines endorse that lifestyle modifications should be considered to be among the key factors for the management of hypertension, especially by/for those people who are categorized as stage 1 hypertensive without other risk factors (Houle et al. 2013).

Among the dietary therapeutic strategies, one of the options is the use of functional foods that have a proven role beyond being nutritious. Flaxseed is one such food item that has been traditionally used in the treatment of cardiovascular diseases (Prasad 2009), and it has also shown success as an antihypertensive in clinical trials (Rodriguez-Leyva et al. 2013). Some studies have also shown Flaxseed to possess a very small hypotensive effect (Prasad 2009), whereas some other studies suggest Flaxseed to selectively be one of the most potent antihypertensives for hypertensive patients (Rodriguez-Leyva et al. 2013). Similarly, a meta-analysis identified the antihypertensive activity of Flaxseed when consumed as a whole for more than 12 weeks (Khalesi et al. 2015). The inconsistent antihypertensive effects, seen during the clinical trial, suggest that background pharmacological screening, which helps in identifying both the therapeutic dose and the possible mechanism involved and which may save from significant drug interactions, was missing as far as the trial was concerned. The studies conducted, so far, on animals have provided limited information on Flaxseed's pharmacological mechanisms (Gogus \& Smith 2010). For instance, a study showed that Flaxseed meal reduced systolic blood pressure (SBP) in spontaneously hypertensive rats (SHR), but the reason for its antihypertensive effect was not provided, though they showed that Flaxseed maintained the intactness of the endothelial lining when compared to how the lining becomes denuded in the diseased control (hypercholesterolemia model) (Talom et al. 1999). Some other studies on the mechanism involved in Flaxseed's antihypertensive effects reported improvements in vascular contractile function (Dupasquier et al. 2006), increase in vasodilator levels (Sekine et al. 2007), inhibition of angiotensin I (Park \& Velasquez 2012; Prasad 2013), and guanylate cyclase inhibition (Prasad 2004). The isolated tissue assembly set-up can give us information about the basic functional mechanism of Flaxseed and help us reflect on the possible involvement of the receptors and dose-response curve (Siddiqi et al. 2014). Therefore, in our study, we aimed to determine the pharmacological mechanism(s) of Flaxseed by using crude aqueous methanolic extract (Fs.Cr) on rat aorta (vascular function), guinea-pig atria (cardiac suppressant effect), and anesthetized rat model, to elucidate mechanistic basis for its medicinal use in hypertension.

\section{MATERIALS AND METHODS}

\section{PLANT MATERIAL AND EXTRACTION}

For the extraction procedure, the Linum usitatissimum L. (Flaxseed) plant material was used, which belongs to the 
family Linaceae (Picture 1). An authentic herbal supplier, located in the local herb market of Karachi, Pakistan, was approached for purchasing the seeds. The Flaxseed that was purchased matched the description of its physical characteristics provided in the online plant list at http:// www.theplantlist.org. The seed was brown and oval, and it had a pointed tip, flat appearance, and a length of about $4 \mathrm{~mm}$. The Flaxseed sample was given a voucher number (LU-SE-0819-001) and deposited in the Barrett Hodgson University's (BHU) herbarium for record.

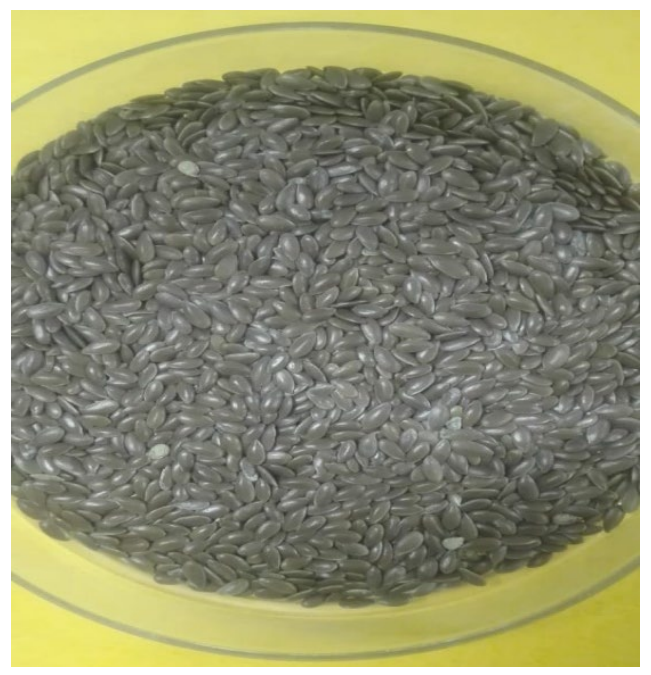

PICTURE 1. Flaxseed (Linum usitatisimum)

For the preparation of the extract, first, the seeds were purified by removing all the dirt and other adulterants. Thereafter, it was finely powdered into powder by using an electrical chopper. To prepare the Fs.Cr from Flaxseed, approximately $1 \mathrm{~kg}$ of ground Flaxseed was cold macerated by using 30:70 v/v aqueous-methanol as a solvent for extraction (Taqvi et al. 2006). The extract was then dried at $40{ }^{\circ} \mathrm{C}$ in rotavapor to obtain Fs.Cr with a yield of $8 \%$.

\section{EXPERIMENTAL ANIMALS}

Adult Sprague-Dawley rats (180-200 g) and guinea-pigs (450-500 g) were used for the in vivo and ex vivo studies, respectively. They were of a local breed and both sexes were used for the experiments. The animals were kept at a controlled temperature $\left(23-25^{\circ} \mathrm{C}\right)$ at an animal house in standard light and dark cycle. They were fed a standard diet and the water supply to them was ad libitum. The protocols devised by the Institute of Laboratory Animal Resources, Commission on Life Sciences, National Research Council, Washington D.C., were adhered to for designing and conducting the study (Council 2010). The study protocol (BHU-ERC/Pharmacy-001/2020/ PI - Dr Amber Hanif Palla) was also approved by the Ethical Research Committee (ERC) of BHU. The animal studies were designed by ensuring the care of animals in line with not only the national and international guidelines but also the institutional guidelines. The doses for the experiments were selected in accordance with the previously reported protocols (Shin et al. 2010).

\section{CHEMICALS}

The chemicals used for the experiments conducted during this study are the following: acetylcholine chloride 
(Ach), isoprenaline hydrochloride, norepinephrine (NE), phenylephrine hydrochloride (PE), and prazosin. These chemicals were bought from Sigma Chemical Company, St. Louis, MO, USA), whereas pentothal sodium (thiopental) was obtained from Abbot Laboratories, Karachi, Pakistan.

\section{PHYTOCHEMICAL ANALYSIS}

The HPLC analysis of Fs.Cr was performed using the Shimadzu (Kyoto, Japan) Prominence 20-AT HPLC System, which was equipped with a binary pump (LC20AT), PDA detector (SPD-M20A), and Kromasil-100 C18 column (Teknokroma, $8 \mu \mathrm{m}, 25 \mathrm{X} 0.46 \mathrm{~mm}$ ) with a membrane filter $(0.45 \mu \mathrm{m})$ and syringe filter $(0.45$ $\mu \mathrm{m})$. The active constituents contained in Fs.Cr were not known erstwhile; however, as the initial screening showed peaks at earlier retention times (a characteristic of non-polar compounds; Ignat et al. 2011), some of the nonpolar compounds whose peaks matched with the extract were used as standards.

For the HPLC analysis, Fs.Cr (2 mg) was dissolved in $2 \mathrm{~mL}$ mobile phase (methanol: acetonitrile: water: acetic acid; 40:20:39:1 v/v) and sonicated for $30 \mathrm{~min}$ to ensure homogenization. It was then filtered through the Millipore filter $(0.45 \mu \mathrm{m})$ to ensure uniform particle size. The flow rate was set at $0.8 \mathrm{~mL} / \mathrm{min}$, and the temperature of $25{ }^{\circ} \mathrm{C}$ was sustained in the column. The wavelength of the ultraviolet detector was set at $254 \mathrm{~nm}$. As no reported standards were available for Fs.Cr at the time of the experiment, activity-guided standard drugs were run parallel to get an idea about the type of compounds present such as quercetin, luteolin, metronidazole, nicotinic acid nicotinamide, and ofloxacin.

\section{MEASUREMENT OF BP IN ANESTHETIZED RATS}

BP was assessed in an anesthetized rat according to the previously defined protocols (Hassan Gilani et al. 2005). At first, the rats were anesthetized by intraperitoneally administering them a dose of $70-90 \mathrm{mg} / \mathrm{kg}$ of thiopental sodium (Pentothal $\left.{ }^{\circledR}\right)$. To provide assisted ventilation, tracheal cannulation was done by using a polyethylene tubing Pe-20. To administer drugs intravenously, cannulation of the right jugular vein was performed with the help of polyethylene tubing Pe-50. For recording the $\mathrm{BP}$, a similar cannulation procedure by the polyethylene tubing was used in the left carotid artery but with the difference that it was pre-filled with heparinized saline $(60 \mathrm{IU} / \mathrm{mL})$. This was done to prevent clogging as this tubing was connected to a pressure transducer (MLT 0380/D Reusable BP-Transducer), which was coupled to ML 224 Quad Bridge Amplifier and Power-Lab ML 4/25 data acquisition system (AD Instruments, Sydney, Australia). To prevent drying of the cannulated exposed surface, a piece of gauze which was moistened in warm saline was kept on it. Before administering any drugs/ test material administration via IV in the jugular vein, heparinized saline $(0.1 \mathrm{~mL})$ was administered in the same tubing to lyse any blood clot that may have formed there and facilitate the smooth administration of the drugs and/or test material. At least $20 \mathrm{~min}$ were given for the heart rate to be stabilized after all the equipment and cannulation settings were put in place. After this, the test substance was injected intravenously, and the arterial $\mathrm{BP}$ was recorded. Before administering the next dose, BP was allowed to be restored to the resting level. The test material was considered antihypertensive if the steadystate values were reduced after the injection. The mean arterial pressure (MAP) was calculated as:

$$
\begin{gathered}
\mathrm{MAP}=\text { Diastolic } \mathrm{BP}+1 / 3 \text { pulse pressure } \\
\text { Pulse pressure }=\mathrm{SBP}-\text { diastolic } \mathrm{BP}
\end{gathered}
$$

The test material was considered to alter MAP if a difference was evident between the resting value before and the lowermost reading after the administration of the test material.

\section{EFFECT ON ISOLATED GUINEA-PIG ATRIA}

To understand the mechanism of test material against spasmogens, a guinea-pig's right atrium was isolated and tested in isolated tissue assembly according to previously defined protocols (Hassan Gilani et al. 2005). The tissue baths of $20 \mathrm{~mL}$ volume were filled with Kreb's solution which was supplied with carbogen gas, and the temperature was maintained at $32{ }^{\circ} \mathrm{C}$ to mimic the mammalian body environment. A guinea-pig's right atrium has the natural automaticity for spontaneous beating due to a pacemaker (Taqvi et al. 2006). The atrium was stabilized for $45 \mathrm{~min}$ before the administration of any drug by using the weights of $1 \mathrm{~g}$ to maintain the resting tension. To record the effect of the drug on isometric contractions, the tissue was connected to an isometric sensor coupled with an amplifier. These were then 
connected to the Power Lab and a computer. The effect of the test material was considered positive if the atrial rate and force of contraction were reduced when compared to their baseline values. The effect was reported as the percentage change in the baseline values.

\section{EFFECT ON RAT AORTA PREPARATIONS}

To study the effect of the test material on aortic preparations, previously defined protocols were used (Tep-Areenan \& Sawasdee 2011). For this purpose, the rats were sacrificed by an overdose of inhalation of the anaesthetic Isoflurane. Once the rats' aorta was dissected, the fat and adipose tissues were excised, and then, 5 $\mathrm{mm}$ long rings were cut, which were then mounted individually in a tissue bath $(5 \mathrm{~mL})$ pre-filled with Kreb's solution. The tissue was connected via a thread to an isometric force transducer (Fort-10, WPI, UK), which was coupled to a bridge amplifier (Transbridge TBM 4M, WPI) and the Power Lab ML 845 data acquisition system. The transducer was used to measure the changes in tension. This was followed by stabilization of the aortic tissue for which Phenylephrine (PE was repeatedly administered to stimulate the alpha receptors that are present on the vessels). Isometric force transducers (Fort-10, WPI, UK) were used to record the contractions of the aorta, and they were further connected with a bridge amplifier (Transbridge TBM 4M, WPI) and the Power Lab ML 845 data acquisition system.

Once the aortic rings were stabilized, the effect of the drug was tested against different spasmogens including high $\mathrm{K}^{+}(80 \mathrm{mM})$, low $\mathrm{K}^{+}(30 \mathrm{mM})$, and PEinduced contractions. If the test material exhibited the inhibitory effect, it would indicate a calcium channel blocking (CCB) activity [L-type voltage-operated] and/or opening of $\mathrm{K}^{+}$channels, respectively. The inhibitory effect of the test material against PEinduced contractions would indicate $\mathrm{Ca}^{++}$influx blocking activity mediated via receptor-operated calcium channels (Godfraind 1986).

\section{STATISTICAL ANALYSIS}

All data were analyzed along with its graphing and calculations by using the GraphPad Prism software version 4.00 for Windows (GraphPad Software, San Diego, CA, USA). The data were presented as Mean \pm Standard error of the mean (SEM), whereas the geometric mean (with 95\% CI) was used to calculate the median EC50 values. Nonlinear regression analysis was used for CRCs. p-values of less than 0.05 were considered statistically significant.

\section{RESULTS}

\section{HPLC OF FLAXSEED EXTRACT}

As is evident in Figure 1(a), HPLC showed the retention time (Rt) of Fs.Cr at $3.075 \mathrm{~min}$, which was close to that of the compound nicotinic acid (2.955 $\mathrm{min} ; 3.54 \mu \mathrm{g} / 2$ $\mathrm{mg}$ ) (Figure 1(c)). This was followed by the Rt of Fs.Cr at $3.387 \mathrm{~min}(6.42 \mu \mathrm{g} / \mathrm{mg})$ which corresponded to that of the compound nicotinamide (3.327 min; Figure 1(d)). Finally, another peak was obtained at $5.608 \mathrm{~min}(9.53$ $\mu \mathrm{g} / \mathrm{mg}$ ) which was comparable to that of the compound quercetin (5.774 min; Figure 1(e)). There were two other peaks identified at $2.789 \mathrm{~min}(19.495 \mu \mathrm{g} / \mathrm{mg})$ and 3.633 $\min (6.195 \mu \mathrm{g} / \mathrm{mg})$ whose Rts matched with the synthetic drugs ofloxacin (an antibiotic) with Rt being $2.835 \mathrm{~min}$ (Figure 1(b)) and metronidazole (an antiamoebic) with Rt of $3.699 \mathrm{~min}$ (Figure 1(f)).

\section{ANTIHYPERTENSIVE EFFECT OF Fs.CR}

The effect of Fs.Cr on invasive BP was assessed in anesthetized rats $(\mathrm{n}=3)$. Fs.Cr decreased MAP by $20 \pm$ $2 \%, 32.5 \pm 2.5 \%$, and $47 \pm 2 \% \mathrm{~mm} \mathrm{Hg}$ for the doses of $10 \mathrm{mg} / \mathrm{kg}, 30 \mathrm{mg} / \mathrm{kg}$, and $100 \mathrm{mg} / \mathrm{kg}$, respectively. Figure 2(A) shows the tracing of the effect of Fs.Cr on BP in an experiment, whereas the combined hypotensive effect of Fs.Cr on MAP in our experiment is depicted in Figure 2(B).

\section{EFFECT OF Fs.CR ON RATE AND FORCE OF CONTRACTION IN GUINEA-PIG ATRIA}

To assess the effect of Fs.Cr on the contractility of the heart, the isolated guinea-pig paired atria was used. As is evident in Figure 3(A), Fs.Cr inhibited the spontaneous rate and force of the contractions which were concentration-dependent with the $\mathrm{EC}_{50}$ values being $4.2 \mathrm{mg} / \mathrm{mL}(95 \% \mathrm{CI}: 3.1-5.2 ; \mathrm{n}=3)$ and $3.7 \mathrm{mg} /$ $\mathrm{mL}(95 \% \mathrm{CI}: 4.6-5.2 ; \mathrm{n}=3)$, respectively. Verapamil similarly inhibited the force and rate of contraction with respective the $\mathrm{EC}_{50}$ values being $2.84 \mu \mathrm{M}(2.46-2.98 ; \mathrm{n}=$ $3)$ and $3.14 \mu \mathrm{M}(2.86-3.42 ; \mathrm{n}=3)$ as shown in Figure 3(B). 
VASODILATOR EFFECT OF Fs.CR ON RAT AORTA

The baseline evaluation of Fs.Cr up to the tested dose of $10 \mathrm{mg} / \mathrm{mL}$ showed that the extract did not exhibit any vasoconstrictor effect in the rat aortic rings (tested data not shown). When tested against the vasoconstrictors such as low \& high $\mathrm{K}^{+}(25$ and $80 \mathrm{mM})$ and PE $(1 \mu \mathrm{M})$ which induce vasoconstriction, Fs.Cr relaxed the vessels against $\mathrm{PE}$ with the $\mathrm{EC}_{50}$ values of $5.7 \mathrm{mg} / \mathrm{mL}$ (4.2-7.4; $\mathrm{n}$ $=3$ ), whereas no inhibitory activity was observed against the contractions induced by low and high $\mathrm{K}^{+}$(Figure $4(\mathrm{~A}))$. The inhibitory effect against PE $(1 \mu \mathrm{M})$-induced vascular contractions was similar to that of prazosin, a standard competitive al receptor antagonist with $\mathrm{EC}_{50}$ values being $0.2 \mathrm{mg} / \mathrm{mL}(0.15-0.28 ; \mathrm{n}=3)$ as shown in Figure 4(B). To further confirm this, CRCs were plotted after the pre-incubation of the rat aortic rings with Fs.Cr ( 1 and $3 \mathrm{mg} / \mathrm{mL}$ ). Expectedly, Fs.Cr at the doses of 1 and $3 \mathrm{mg} / \mathrm{mL}$ shifted the PE-CRCs to the right in a parallel manner without the suppression of the maximum response (Figure 5(A)). This rightward parallel shift in the PE-curves was similar to that obtained in the case of pretreatment of prazosin (0.01-0.03 $\mu \mathrm{M} ; \mathrm{n}=3)$ as shown in Figure 5(B), thus, confirming the presence of a competitive alpha 1 antagonist type.

No significant difference $(>0.05)$ was observed in the $\mathrm{EC}_{50}$ values when Fs.Cr was tested in the E-intact and E-denuded aorta (Figure 6). Atropine pre-incubation did not change the $\mathrm{EC}_{50}$ values (Figure 6), thus indicating a lack of the anticholinergic and cGMP-dependent mechanisms' involvement in blood vessels.

\section{DISCUSSION}

Flaxseed has traditionally been used to manage cardiovascular disorders including hypertension (Prasad 2019). Recently, Flaxseed has gained a lot of attention because of its numerous cardiovascular health benefits that are attributed to the soluble fibres, $\alpha$-linolenic acid (ALA) and lignans (phytoestrogens) in it (Jhala \& Hall 2010). Several clinical trials have been conducted to assess its antihypertensive effects (RodriguezLeyva et al. 2013), but the data available about the pharmacological rationale for its effectiveness is limited.

In view of this, we evaluated the antihypertensive effect of Fs.Cr in an anesthetized rat and studied the possible mechanisms in an isolated tissue assembly set up using guinea-pig atria and rat aorta.

Our study shows that Fs.Cr when administered intravenous (IV), reduces the rat's arterial BP dose- dependently. This finding of ours is consistent not only with Flaxseed's known traditional use but also with the previous reports of research (Prasad 2009, 2004) that found Flaxseed to significantly reduce MAP in animals when administered IV (Prasad 2009), which is why it was possibly used in clinical trials.

Surprisingly, the results of the clinical trials were inconclusive. In some of these trials, there was a marked antihypertensive response (Rodriguez-Leyva et al. 2013), whereas such a response was either marginal or absent in others (Khalesi et al. 2015; Prasad 2009). The inconsistency of Flaxseed (difficulty in dissolution with water) has been reported earlier by Palla et al. (2016), which was also supported by the previous findings in this regard where Secoisolariciresinol diglucoside (SDG)rich Flaxseed significantly lowered SBP in animals only in the presence of a high-fat diet administration (Park \& Velasquez 2012), whereas in the case of IV administration, the effects were marked and independent of high fat reflecting an issue in its oral absorption (Park $\&$ Velasquez 2012). It is proposed, therefore, that our future studies will address this aspect of inconsistent effects because it is possible to derive more health-related benefits from this plant if we understand the optimal method of its intake.

To evaluate Flaxseed's mechanism of action, isolated tissue preparations are routinely used as then the tissues' response is not interfered with by the reflex actions of the body (Ajay et al. 2007). Rat thoracic aorta is routinely used for assessing the effect on underlying pharmacodynamics of BP-lowering effects, i.e., vascular resistance. Flaxseed extract was tested against low and high $\mathrm{K}^{+}$, as well as, against PE-induced contractions in rat aorta to distinguish whether Flaxseed mediates its antihypertensive activity by the $\mathrm{K}^{+}$channels' opening, or the blocking of voltage-operated channels and/or the receptor-operated calcium channels, respectively (Okmura et al. 1993). As Fs.Cr selectively inhibited the PE-induced contractions in the aortic rings with no significant inhibition against low and high $\mathrm{K}^{+}$, it indicated that it may be acting through the receptor-operated calcium channels. The effect of these receptor-operated channels was similar to the $\alpha-1$ receptor owing to the former's rightward parallel shift (Doggrell 1992). The $\alpha-1$ receptor's blocking of the activity of Fs.Cr was confirmed when the pre-incubation of the aortic rings with Fs.Cr caused the rightward but parallel shift in the PE-CRCs that was similar to the shift in the case of prazosin, a competitive $\alpha-1$ antagonist (Doggrell 1992). 
This is an important finding because functional data of this sort has not been reported so far. It reflects on the basic mechanism by which Flaxseed may contribute to its antihypertensive effect. It has been reported through a series of clinical trials that $\alpha 1$-receptor antagonists lower total peripheral resistance and reduce left ventricular hypertrophy even as they improve glomerular filtration rate (Schmieder et al. 1996). Together, these contribute to the improvement in BP. Thus, the inhibitory effect of Flaxseed may be due to the competitive alpha-1 antagonist effect that may cause vasodilation, the subsequent decrease in peripheral vascular resistance, and ultimately contribute to a reduction of BP.

In our experiments, we did not observe any difference in the effects on intact versus denuded aorta. Possibly, this means that for the tested doses, Flaxseed does not mediate its hypotensive effect via the L-arginineNO pathway. This is consistent with the previous reports where SDG, lignin isolated from Flaxseed, did not mediate its effect via the stimulation of the NO synthase pathway and rather mediated the hypotensive effect by the cGMP pathway (Prasad 2004). Similarly, dietary Flaxseed could also not attenuate endothelial vasodilation mechanism when administered along with a cholesterol diet for a prolonged time (Dupasquier et al. 2006). As can be noted from the results, the $\alpha-1$ antagonist effect is mediated at a higher dose of $1 \mathrm{mg} / \mathrm{mL}$. Therefore, the possibility of other mechanisms cannot be excluded.

As both the blood vessels and the heart simultaneously play a role in maintaining $\mathrm{BP},(\mathrm{BP}=$ cardiac output $\times$ peripheral vascular resistance [PVR]), the effect of Fs.Cr was studied on isolated guinea-pig atria to understand whether Fs.Cr also affects cardiac contractility. It was found that Fs.Cr reduced the rate and force of contraction similar to how verapamil, a non-specific $\mathrm{Ca}^{++}$ channel blocker that predominantly acts on L-type $\mathrm{Ca}^{++}$ channels, does it. This CCB-like activity is consistent with our previous studies in which Fs.Cr mediated its antispasmodic activities by blocking the $\mathrm{Ca}^{++}$channels (Palla et al. 2015). It is interesting to note that Fs.Cr did not exhibit any CCB-like activity in vessels as it did not inhibit high $\mathrm{K}^{+}$-induced contraction. It is possible that Fs.Cr mediates tissue-specific actions as reported in the case of other plant materials (Xiao et al. 2006), hence, its CCB activity is specific for the heart and gut tissues but not so in the vessels. Understandably, the difference in terms of the presence of a different type of receptors could be attributed to this specificity as the heart predominantly has L-type $\mathrm{Ca}^{++}$channels that are highly responsive to verapamil, whereas the blood vessels predominantly have T-type $\mathrm{Ca}^{++}$channels (Katz 1996). Thus, it seems that Fs.Cr may mediate its CCB-like activity via the L-type $\mathrm{Ca}^{++}$channels that could be attributed to its cardiodepressant effect caused by a reduction in the rate and force of the contraction of the heart in guinea-pig atria and reduction of SBP in the anesthetized rat. This coupled with the alpha- 1 antagonist effect on blood vessels may be responsible for the antihypertensive activity of Fs.Cr. The antihypertensive effect of Fs.Cr could be more marked in hypertensive rats because of increased expression of the L-type $\mathrm{Ca}^{++}$channels in them and the consequent $\mathrm{Ca}^{++}$ influx leading to abnormal arterial tone (Sonkusare et al. 2006).

Besides these mentioned antihypertensive mechanisms, several other mechanisms have been reported that are attributed to the antihypertensive activity of Flaxseeds including the angiotensin-converting enzyme inhibition (ACEI) and guanylate cyclase inhibition-like activities (Prasad 2013, 2009)

Besides, the extract that we used in the experiments conducted for this study, various other forms of Flaxseed, including milled Flaxseed, Flaxseed oil, defatted Flaxseed meal (rich in protein), Flaxseed protein hydrolysate (FPH), and SDG (lignin of Flaxseed), have been studied previously for deciphering their antihypertensive mechanisms. SDG has been shown to mediate antihypertensive effect via the guanylate cyclase inhibition (Prasad 2013), whereas both Flaxseed oil and SDG have shown ACEI activity (Ogawa et al. 2009; Prasad 2013). Flaxseed oil has been shown to reduce BP with simultaneous production of PGI 2 and NO metabolites, possibly, through the bradykinin stimulation (Sekine et al. 2007). Milled flaxseed has shown an antihypertensive effect that corresponds to the level of oxylipins, and this activity was associated with the presence of alpha-linolenic acid (ALA) in Flaxseed, which is a component found in high quantities in Flaxseed oil and whole seed (Caligiuri et al. 2014). FPH has been shown to exhibit antihypertensive activity in SHR by ACEI and renin inhibition (Udenigwe et al. 2009). Hence, taken together as a whole, and based on the findings of this study, we are reporting for the first time that Flaxseed extract mediates its antihypertensive effect as $\mathrm{CCB}$ on the heart and vasodilation that is mediated via the alpha- 1 antagonism activity in the blood vessels. This coupled with reasons surfaced in the previous reports for the vasodilatory activity mediated via the guanylate cyclase 
inhibition, PGI2, and NO production, and ACE and renin inhibition activity may be the contributory factors for the overall antihypertensive effect of Flaxseed (Kumeshini et al. 2016). Therefore, Flaxseed as a whole has immense antihypertensive potential provided we use an optimal method for its administration that ensures absorption of the polar as well as the non-polar constituents.

This study is the first to report the fingerprint analysis of Flaxseed extract using HPLC. So far, there are no standards reported for the use of Flaxseed extract, which was obtained by using 70:30 ethanolwater. The components so far reported for flaxseed are representative of its polar constituents such as ALA. Therefore, for the extract, we identified the compounds by matching the peaks with the closest retention times of known compounds which corresponded to nicotinic acid, nicotinamide, quercetin, ofloxacin, and metronidazole. The antihypertensive mechanism observed in this study is relatable to the HPLC's findings, as quercetin, an antioxidant compound found in Fs.Cr, has previously shown antihypertensive activity in both rodents and hypertensive humans (Edwards et al. 2007) along with ACEI-like activity as the possible antihypertensive mechanism (Mackraj et al. 2008). Quercetin has also been reported to mediate antihypertensive activity via the increased endothelial nitric oxide synthase (eNOS) activity and consequent increase in NO (Sanchez et al. 2006; Yamamoto \& Oue 2006). In our study, Fs.Cr did not mediate its vasodilatory activity via the NO pathway, possibly, because we used normotensive Sprague Dawley rats, whereas quercetin effects were observed only in SHR and not in Wistar-Kyoto (WK) rats. Besides quercetin, nicotinic acid, identified as one of the compounds in Fs.Cr, has been shown to reduce BP in hypertensive humans (Gadegbeku et al. 2003). Interestingly, a novel combination of quercetin and nicotinic acid has exhibited an antihypertensive effect in SHR but not in WK rats (Wang et al. 2014). This aspect indicates that
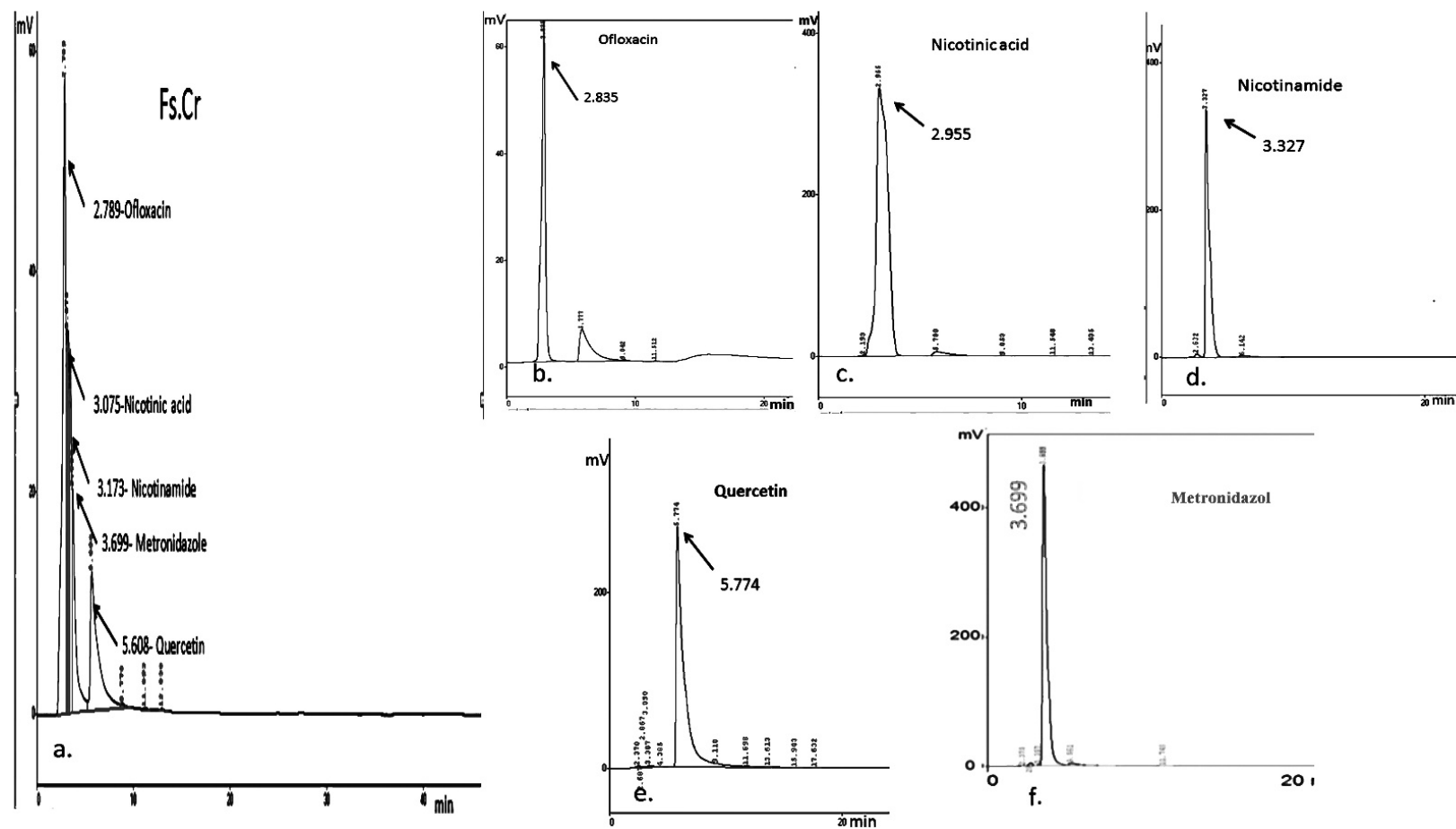

FIGURE 1. High performance liquid chromatography (HPLC) fingerprints of (a) Fs.Cr. Peaks of Fs.Cr resemble with nicotinic acid $(\mathrm{Rt}=2.955)$, nicotinamide $(\mathrm{Rt}=3.327)$ and quercetin $(\mathrm{Rt}=5.774)$. Other unidentified compounds matching synthetic compounds ofloxacin $(\mathrm{Rt}=2.835)$ and metronidazole $(\mathrm{Rt}=3.699)$. Peaks identified in Figure indicate retention time (in min) of respective compounds, (b) peaks of Fs.Cr resemble with ofloxacin ( $\mathrm{Rt}=2.835$ ),

(c) nicotinic acid ( $\mathrm{Rt}=2.955)$, (d) nicotinamide ( $\mathrm{Rt}=3.327)$, (e) quercetin ( $\mathrm{Rt}=5.774)$ and (f) metronidazole $(\mathrm{Rt}=3.699)$. Peaks identified in Figure indicate retention time (in $\mathrm{min}$ ) of respective compounds 
A

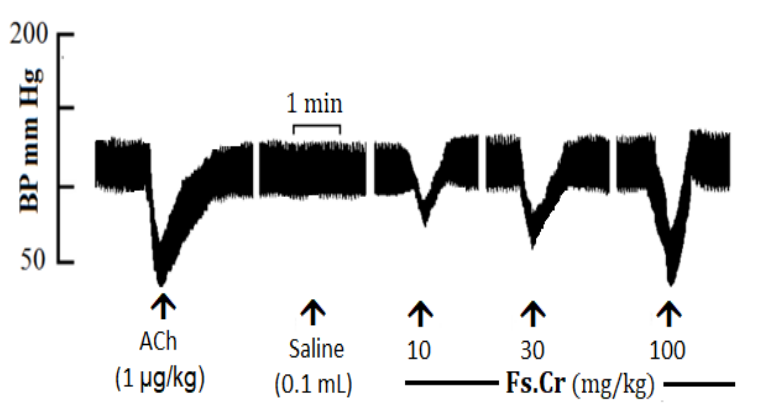

B

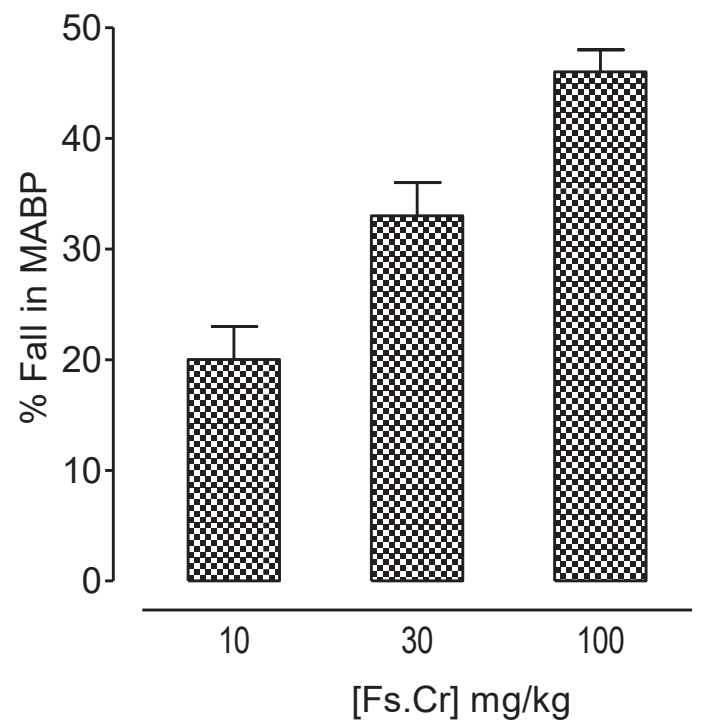

FIGURE 2. Panel (A) shows a typical tracing of Flaxseed crude extract (Fs.Cr) blood pressure (BP)-lowering effect and Panel (B) shows a bar chart representing hypotensive effect of Fs.Cr on mean arterial blood pressure (MAP) in anesthetized rats. The dose was administered after the response to the preceding one had returned to normal. Values shown represent mean \pm SEM, $n=3$
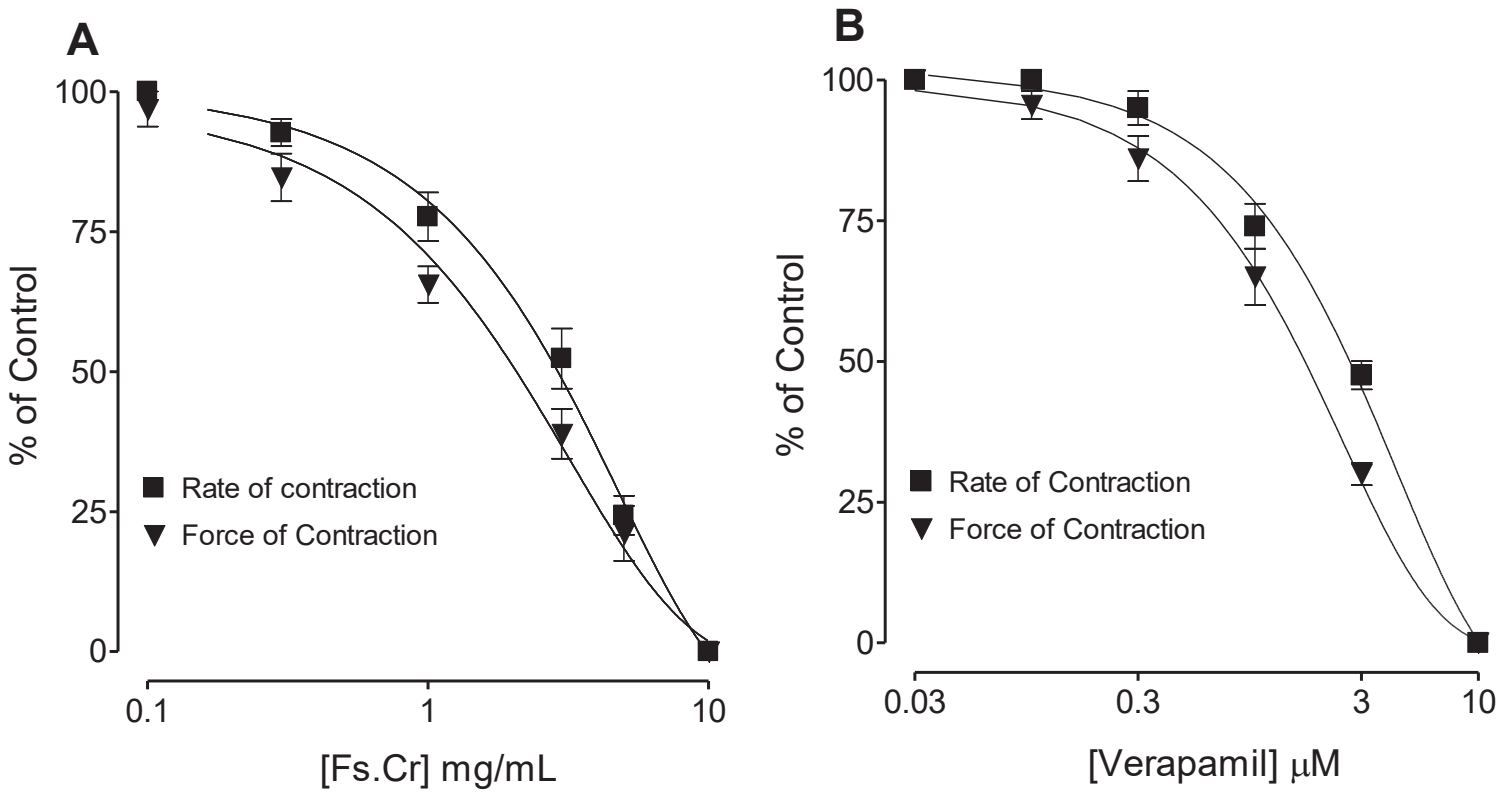

FIGURE 3. Inhibitory effect of Flaxseed crude extract (Fs.Cr) (A) and verapamil (B) on force and rate of spontaneous contractions in isolated guinea pig right atria. Values shown are mean \pm SEM, $\mathrm{n}=3$ 
A

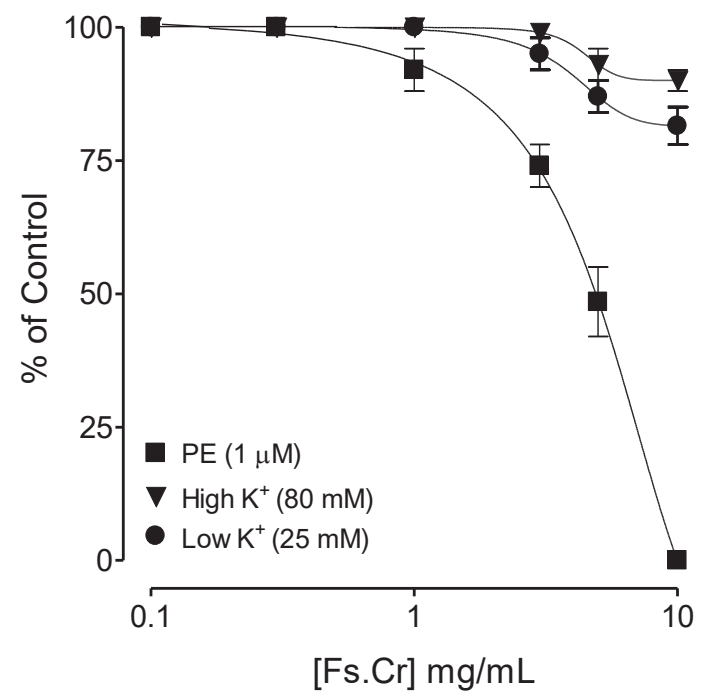

\section{B}

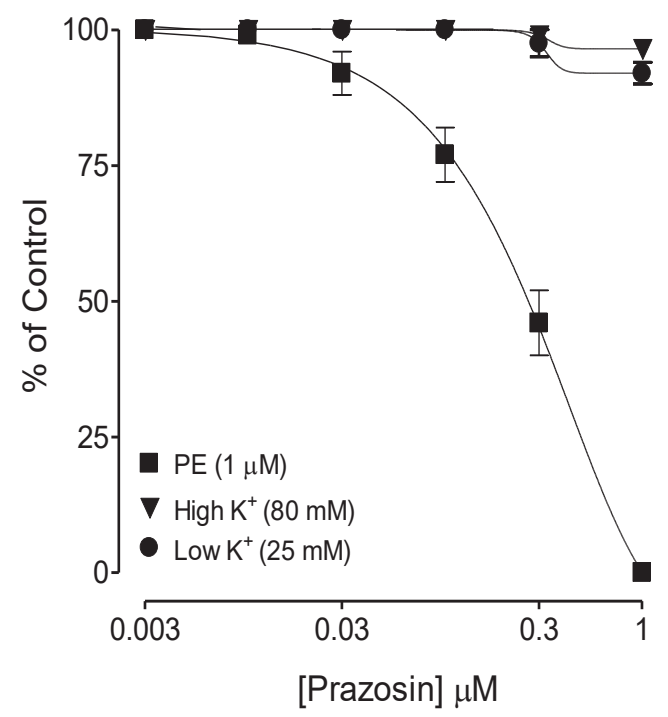

FIGURE 4. Concentration-dependent relaxant effects of (A) Flaxseed crude extract (Fs. $\mathrm{Cr}$ ) and (B) prazosin on Low $\mathrm{K}^{+}$, high $\mathrm{K}^{+}$and phenylephrine (PE)-induced contractions in isolated rat aortic ring preparations. Values shown are mean $\pm S E M, n=3$
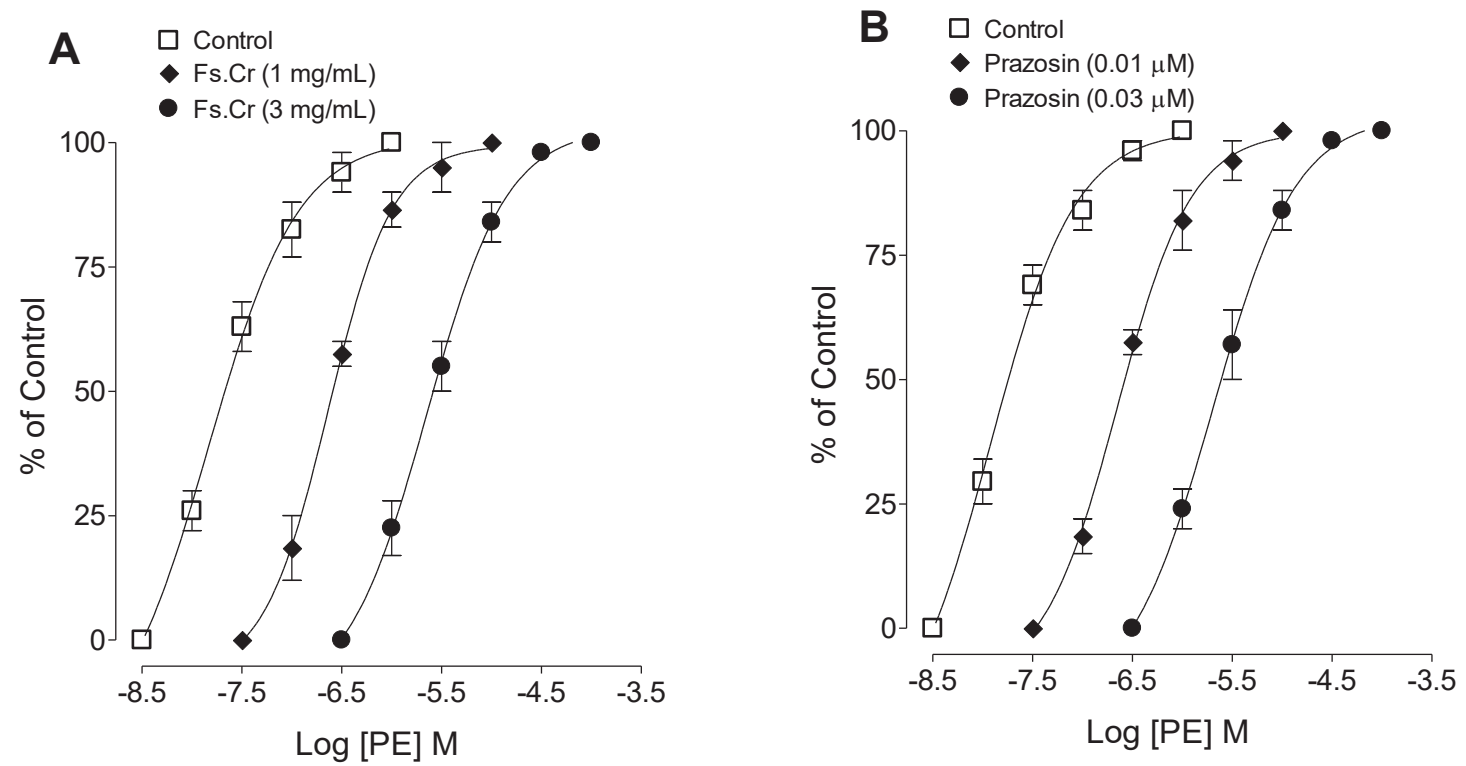

FIGURE 5. Concentration-response curves of phenylephrine (PE) in the absence and presence of different concentrations of (A) Flaxseed crude extract (Fs.Cr) and (B) prazosin in isolated rat aortic ring preparations. Values shown are mean $\pm \mathrm{SEM}, \mathrm{n}=3$ 


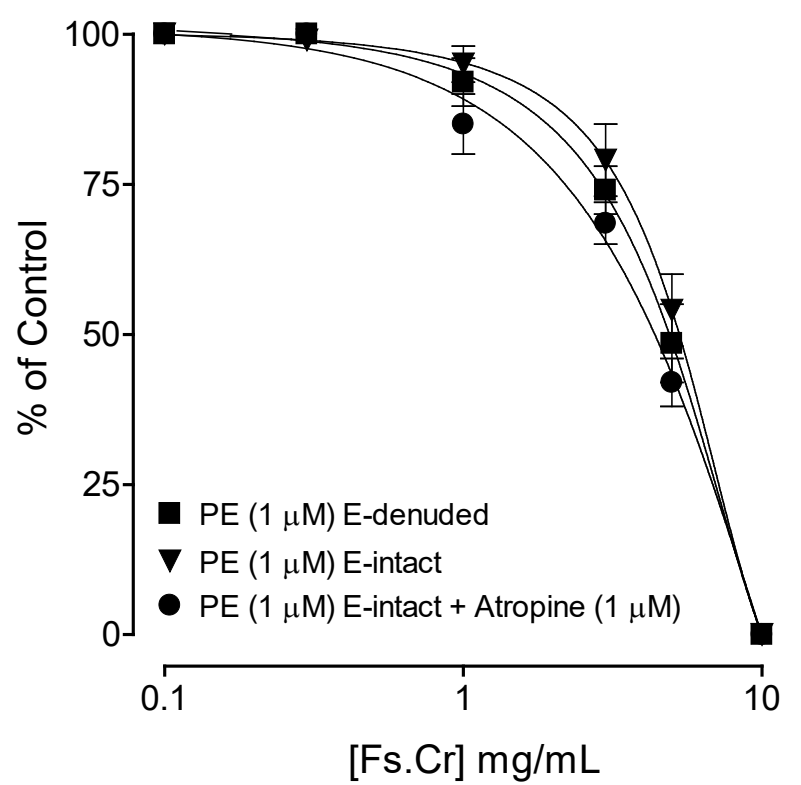

FIGURE 6. Concentration-dependent relaxant effects of Flaxseed crude extract (Fs.Cr) on phenylephrine (PE)-induced contractions in the absence and presence of atropine $(1 \mu \mathrm{M})$ in endothelium (E)-intact and E-denuded isolated rat aortic ring preparations. Values shown are mean $\pm S E M, n=3$

Flaxseed, by virtue of their active constituents, may have both the tissue- and specimen-specific effects as we have mentioned earlier that CCB-like activity was evident in atria and not in aorta. Therefore, our future studies may be focussed on assessing the mechanisms of Flaxseed in different species and on different tissues.

This study has certain limitations. We were not able to demonstrate the pharmacological mechanism attributed to inhibitory activity in the guinea-pig atria. In our future studies, we will aim to determine the possibility of beta-blocking and/or the presence of the anticholinergic component in the atria to confirm these mechanisms. Another limitation was that we selected rats of both sexes. The effect of female hormones has been evident in the prevention of hypertension. It has been reported earlier that female rats who were ovariectomized became hypertensive in four weeks (Kumeshini et al. 2016). However, hypertension in ovariectomized rats was evident only when fed with a $2 \%$ cholesterol diet, indicating that the protection from hypertension in them was attributed to a reduction in their dyslipidaemic parameters (Kumeshini et al. 2016). Hence, the hormonal aspect in the female rats used may have had a lesser impact on the findings of this study, as this study is a mechanistic study, and we performed it on normotensive rats, which were on a normal diet. Nevertheless, earlier studies have consistently shown a difference in the cardiovascular disease parameters in males and females with the male and postmenopausal women being at greater risk of cardiovascular diseases when compared to premenopausal or adolescent females (Blenck et al. 2016). In accordance with the new guidelines issued by the National Institute of Health about considering the biological sex as a potential experimental variable in both animal and human studies focused on cardiovascular diseases (Blenck et al. 2016), our future mechanistic studies would certainly consider male and female animals as separate groups. 


\section{CONCLUSION}

In conclusion, Fs.Cr exhibits BP-lowering, cardiodepressant, and vasodilator effects. The mechanism involved in vasodilation by Flaxseed is possibly mediated by competitive inhibition of the alpha-1 adrenergic receptors. However, further studies are needed to elucidate the cardiac depressant effects.

\section{ACKNOWLEDGEMENTS}

This publication was supported by the Deanship of Scientific Research, Prince Sattam Bin Abdulaziz University, Al Kharj, KSA.

\section{REFERENCES}

Ajay, M., Chai, H., Mustafa, A., Gilani, A.H. \& Mustafa, M.R. 2007. Mechanisms of the anti-hypertensive effect of Hibiscus sabdariffa L. calyces. Journal of Ethnopharmacology 109(3): 388-393.

Blenck, C.L., Harvey, P.A., Reckelhoff, J.F. \& Leinwand, L.A. 2016. The importance of biological sex and estrogen in rodent models of cardiovascular health and disease. Circulation Research 118(8): 1294-1312.

Caligiuri, S.P., Aukema, H.M., Ravandi, A., Guzman, R., Dibrov, E. \& Pierce, G.N. 2014. Flaxseed consumption reduces blood pressure in patients with hypertension by altering circulating oxylipins via an $\alpha$-linolenic acid-induced inhibition of soluble epoxide hydrolase. Hypertension 64(1): 53-59.

Council National Research (NRC). 2010. Guide for the Care and Use of Laboratory Animals. Washington: National Academies Press pp. 1-7.

Cutler, J.A., Sorlie, P.D., Wolz, M., Thom, T., Fields, L.E. \& Roccella, E.J. 2008. Trends in hypertension prevalence, awareness, treatment, and control rates in United States adults between 1988-1994 and 1999-2004. Hypertension 52(5): 818-827.

Doggrell, S.A. 1992. An analysis of the inhibitory effects of prazosin on the phenylephrine response curves of the rat aorta. Naunyn-Schmiedeberg's Archives of Pharmacology 346(3): 294-302.

Dupasquier, C.M., Weber, A.M., Ander, B.P., Rampersad, P., Steigerwald, S. \& Wigle, J.T., Mitchell, R.W., Kroeger, E.A., Gilchrist, J.S.C., Moghadasian, M.M., Lukas, A. \& Pierce, G.N. 2006. Effects of dietary flaxseed on vascular contractile function and atherosclerosis during prolonged hypercholesterolemia in rabbits. American Journal of Physiology-Heart and Circulatory Physiology 291(6): H2987-H2996.

Edwards, R.L., Lyon, T., Litwin, S.E., Rabovsky, A., Symons, J.D. \& Jalili, T. 2007. Quercetin reduces blood pressure in hypertensive subjects. The Journal of Nutrition 137(11): 2405-2411.
Gadegbeku, C.A., Dhandayuthapani, A., Shrayyef, M.Z. \& Egan, B.M. 2003. Hemodynamic effects of nicotinic acid infusion in normotensive and hypertensive subjects. American Journal of Hypertension 16(1): 67-71.

Ghayur, M.N. \& Janssen, L.J. 2010. A natural way to cardiovascular health. Nature Reviews Cardiology 7(3): 174.

Godfraind, T. 1986. EDRF and cyclic GMP control gating of receptor-operated calcium channels in vascular smooth muscle. European Journal of Pharmacology 126(3): 341343.

Gogus, U. \& Smith, C. 2010 - n-3 Omega fatty acids: A review of current knowledge. International Journal of Food Science and Technology 45(3): 417-436.

Hassan Gilani, A., Khan, A.U., Jabbar Shah, A., Connor, J. \& Jabeen, Q. 2005. Blood pressure lowering effect of olive is mediated through calcium channel blockade. International Journal of Food Sciences and Nutrition 56(8): 613-620.

Houle, S.K., Padwal, R. \& Tsuyuki, R.T. 2013. The 20122013 Canadian Hypertension Education Program (CHEP) guidelines for pharmacists: An update. Canadian Pharmacists Journal/Revue des Pharmaciens du Canada 146(3): 146-150.

Ignat, I., Volf, I. \& Popa, V.I. 2011. A critical review of methods for characterization of polyphenolic compounds in fruits and vegetables. Food Chemistry 126(4): 18211835 .

Jhala, A.J. \& Hall, L.M. 2010. Flax (Linum usitatissimum L.): Current uses and future applications. Australian Journal of Basic and Applied Sciences 4(9): 4304-4312.

Katz, A.M. 1996. Calcium channel diversity in the cardiovascular system. Journal of the American College of Cardiology 28(2): 522-529.

Khalesi, S., Irwin, C. \& Schubert, M. 2015. Flaxseed consumption may reduce blood pressure: A systematic review and meta-analysis of controlled trials. The Journal of Nutrition 145(4): 758-765.

Kumeshini, S., Nurshazana, A., Faizah, O., Kamsiah, J., Srijit, D. \& Chi, Z.T. 2016. Development of hypertensive animal model using ovariectomised rat fed with short-term $2 \%$ cholesterol diet. Medicine and Health 11(2): 171-180.

Mackraj, I., Govender, T. \& Ramesar, S. 2008. The antihypertensive effects of quercetin in a salt-sensitive model of hypertension. Journal of Cardiovascular Pharmacology 51(3): 239-245.

Mazzaglia, G., Ambrosioni, E., Alacqua, M., Filippi, A., Sessa, E. \& Immordino, V., Borghi, C., Brignoli, O., Caputi, A.P., Cricelli, C. \& Mantovani, L.G. 2009. Clinical perspective. Circulation 120(16): 1598-1605.

Ogawa, A., Suzuki, Y., Aoyama, T. \& Takeuchi, H. 2009. Dietary alpha-linolenic acid inhibits angiotensin-converting enzyme activity and mRNA expression levels in the aorta of spontaneously hypertensive rats. Journal of Oleo Science 58(7): 355-360. 
Okmura, K., Ichihara, K., Nagaska, M., Oda, N. \& Tajima, K. 1993. Calcium entry blocking activities of MPC-1304 and of its enantiomers and metabolites. European Journal of Pharmacology 235(1): 69-74.

Palla, A.H., Iqbal, N.T., Minhas, K. \& Gilani, A.H. 2016. Flaxseed extract exhibits mucosal protective effect in acetic acid induced colitis in mice by modulating cytokines, antioxidant and anti-inflammatory mechanisms. International Immunopharmacology 38: 153-166.

Palla, A.H., Khan, N.A., Bashir, S., Iqbal, J. \& Gilani, A.H. 2015. Pharmacological basis for the medicinal use of Linum usitatissimum (Flaxseed) in infectious and noninfectious diarrhea. Journal of Ethnopharmacology 160: 61-68.

Park, J.B. \& Velasquez, M.T. 2012. Potential effects of lignanenriched flaxseed powder on bodyweight, visceral fat, lipid profile, and blood pressure in rats. Fitoterapia 83(5): 941-946.

Prasad, K. 2019. Importance of Flaxseed and its components in the management of hypertension. International Journal of Angiology 28(3): 153-160

Prasad, K. 2013. Secoisolariciresinol diglucoside (SDG) isolated from flaxseed, an alternative to ACE inhibitors in the treatment of hypertension. International Journal of Angiology 22(4): 235-238.

Prasad, K. 2009. Flaxseed and cardiovascular health. Journal of Cardiovascular Pharmacology 54(5): 369-377.

Prasad, K. 2004. Antihypertensive activity of secoisolariciresinol diglucoside (SDG) isolated from flaxseed: Role of guanylate cyclase. International Journal of Angiology 13(1): 7-14.

Rodriguez-Leyva, D., Weighell, W., Edel, A.L., LaVallee, R., Dibrov, E. \& Pinneker, R., Maddaford, T.G., Ramjiawan, B., Aliani, M., Guzman, R. \& Pierce, G.N. 2013. Potent antihypertensive action of dietary flaxseed in hypertensive patients. Hypertension 62(6): 1081-1089.

Sanchez, M., Galisteo, M., Vera, R., Villar, I.C., Zarzuelo, A., Tamargo, J., Pérez-Vizcaíno, F. \& Duarte, J. 2006. Quercetin downregulates NADPH oxidase, increases eNOS activity and prevents endothelial dysfunction in spontaneously hypertensive rats. Journal of Hypertension 24(1): 75-84.

Schmieder, R.E., Langenfeld, M.R., Friedrich, A., Schobel, H.P., Gatzka, C.D. \& Weihprecht, H. 1996. Angiotensin II related to sodium excretion modulates left ventricular structure in human essential hypertension. Circulation 94(6): 1304-1309.

Sekine, S., Sasanuki, S., Aoyama, T. \& Takeuchi, H. 2007. Lowering systolic blood pressure and increases in vasodilator levels in SHR with oral $\alpha$-linolenic acid administration. Journal of Oleo Science 56(7): 341-345.

Shin, J.W., Seol, I.C. \& Son, C.G. 2010. Interpretation of animal dose and human equivalent dose for drug development. The Journal of Korean Oriental Medicine 31(3): 1-7.
Siddiqi, H.S., Majeed, A. \& Gilani, A.H. 2014. Pharmacological basis for the medicinal use of Wrightia tinctoria in hypertension and dyslipidemia. Journal of Cardiovascular Pharmacology 64(2): 151-163.

Sonkusare, S., Palade, P.T., Marsh, J.D., Telemaque, S., Pesic, A. \& Rusch, N.J. 2006. Vascular calcium channels and high blood pressure: Pathophysiology and therapeutic implications. Vascular Pharmacology 44(3): 131-142.

Talom, R.T., Judd, S.A., McIntosh, D.D. \& McNeill, J.R. 1999. High flaxseed (linseed) diet restores endothelial function in the mesenteric arterial bed of spontaneously hypertensive rats. Life Sciences 64(16): 1415-1425.

Taqvi, S.I., Aftab, M.T., Ghayur, M.N., Gilani, A.H. \& Saify, Z.S. 2006. Synthesis and biological evaluation of 1-(2', 4'-dimethoxyphenacyl)-4-acetyl-4-phenylpiperidinium bromide in intestinal and cardiovascular tissues. Journal of Pharmacology Toxicology 1: 126-133.

Tep-Areenan, P. \& Sawasdee, P. 2011. The vasorelaxant effects of Anaxagorea luzonensis A. Grey in the rat aorta. International Journal of Pharmacology 7: 119-124.

Udenigwe, C.C., Lin, Y.S., Hou, W.C. \& Aluko, R.E. 2009 Kinetics of the inhibition of renin and angiotensin I-converting enzyme by flaxseed protein hydrolysate fractions. Journal of Functional Foods 1(2): 199-207.

Wang, Z., Yang, L., Cui, S., Liang, Y. \& Zhang, X. 2014. Synthesis and anti-hypertensive effects of the twin drug of nicotinic acid and quercetin tetramethyl ether. Molecules 19(4): 4791-4801.

Xiao, C.W., Wood, C., Huang, W., RL'Abbé, M., Gilani, G.S., Gerard, M.C. \& Curran, I. 2006. Tissue-specific regulation of acetyl-CoA carboxylase gene expression by dietary soya protein isolate in rats. British Journal of Nutrition 95(6): 1048-1054.

Yamamoto, Y. \& Oue, E. 2006. Antihypertensive effect of quercetin in rats fed with a high-fat high-sucrose diet. Bioscience, Biotechnology, and Biochemistry 70(4): 933-939.

\section{Amber Hanif Palla}

Faculty of Pharmacy

Department of Basic Medical Sciences

Salim Habib University

(formerly Barrett Hodgson University), Karachi

Pakistan

Najeeb Ur Rehman*

Department of Pharmacology and Toxicology

College of Pharmacy

Prince Sattam Bin Abdulaziz University

Al-Kharj, 11942

Saudi Arabia

Amber Hanif Palla \& Hasan Salman Siddiqi

Faculty of Biological and Biomedical Sciences

The Aga Khan University Hospital and Medical College, Karachi

Pakistan 
Anwar-ul-Hassan Gilani

The University of Haripur

Haripur, Khyber Pakhtunkhwa

Pakistan

Bina Shaheen Siddiqui, Maimoona Ilyas \& Sobiya Perwaiz H.E.J. Research Institute of Chemistry

International Centre for Chemical and Biological Sciences

University of Karachi

Karachi, Sindh 75270

Pakistan
Sobiya Perwaiz

Federal Urdu University

Karachi

*Corresponding author; email: n_rehman5@hotmail.com

Received: 4 October 2020

Accepted: 26 January 2021 